\title{
ANALISIS WACANA KRITIS PADA BERITA KRIMINAL SURAT KABAR POSMETRO PADANG
}

\author{
Silvia Permata Sari \\ Universitas Putra Indonesia YPTK Padang \\ Silvia permata.sari@yahoo.co.id
}

\begin{abstract}
Abstrak
Understanding of the hidden intent or meaning behind the news texts can be known through critical discourse analysis. The basic understanding of critical discourse analysis is that discourse is not understood merely as an object of study of language but language as a tool used for certain purposes and practices including ideological and power practices. The data of this research are news texts with criminal problems in the newspaper Posmetro Padang. The source of this research data is the daily news of Posmetro Padang. Theo van Leeuwen's critical discourse analysis model is one of six critical discourse analysis models that allow the reader to know how a group or someone is marginalized or even favored in a news discourse. In addition, it helps so that readers can think more critically in analyzing a news discourse. Not only read but understand and interpret it so that it can know the hidden purpose in the news text.
\end{abstract}

Kata kunci: Analisis wacana kritis, berita kriminal, surat kabar

\section{PENDAHULUAN}

Setelah masa Orde Baru, penyajian berita dalam media massa memberikan gambaran kebebasan pers yang 'benar-benar bebas'. Kebebasan pers tersebut juga memberikan pengaruh bagi wartawan. Wartawan yang sejatinya memberitakan kebenaran, saat ini telah dipengaruhi oleh kelompok-kelompok tertentu atau pihak-pihak yang mempunyai kekuasaan dalam menyajikan peristiwa yang diberitakan. Hal ini dilakukan oleh kelompok-kelompok tersebut yang bertujuan untuk memperjuangkan ideologinya maupun juga memarjinalkan ideologi yang lain. Oleh karena itu, wartawan cenderung tidak netral dalam menulis berita.

Pemahaman terhadap maksud atau makna yang tersembunyi di balik teks-teks berita tersebut dapat diketahui melalui analisis wacana kritis. Pemahaman dasar analisis wacana kritis adalah wacana tidak dipahami semata-mata sebagai objek studi bahasa tetapi bahasa sebagai alat yang digunakan untuk tujuan dan praktik tertentu termasuk praktik ideologi dan kekuasaan. Jadi, analisis wacana kritis memandang media sebagai salah satu 'ladang' yang digunakan oleh kelompok-kelompok tertentu untuk memperjuangkan kelompoknya dan memarjinalkan kelompok lain.

Analisis wacana kritis yang dibahas dalam makalah ini adalah model analisis wacana kritis menurut Theo van Leeuwen yang mengemukakan cara peristiwa dan pelaku sosial atau kelompok tertentu ditampilkan dalam sebuah wacana pemberitaan. Model ini dapat menjelaskan cara suatu peristiwa, kelompok, atau seseorang dimarjinalkan posisinya dalam sebuah wacana pemberitaan sehingga yang terlihat hanya keburukan salah satu pihak saja dan menutupi alasan satu pihak melakukan suatu tindakan. Keadaan seperti ini dalam teks media terjadi karena adanya pihak yang 
sengaja dikeluarkan (eksklusi) dan dilibatkan/dimasukkan (inklusi) oleh wartawan sehingga teks akan membentuk pemahaman tertentu sebagaimana wartawan memahami peristiwa tersebut.

\section{TINJAUAN LITERATUR}

Darma (2009:49) mengungkapkan analisis wacana kritis merupakan sebuah upaya atau proses penguraian untuk memberikan kejelasan dari sebuah teks (realitas sosial) yang mau atau sedang dikaji oleh seseorang atau kelompok dominan yang mempunyai tujuantertentu untuk memperoleh apa yang diinginkan. Analisis wacana kritis mengkaji tentang upaya kekuatan sosial, dominasi, dan kepentingan yang direproduksi dan dipertahankan melalui teks yang pembahasannya dihubungkan dengan konteks sosial dan politik mempunyai tujuan dan asumsi.

Alwi (1993:471) mengatakan wacana adalah satuan bahasa terlengkap. Wacana merupakan satuan bahasa terlengkap dalam hierarki gramatikal merupakan satuan gramatikal tertinggi atau terbesar. Sumarlan (2003:15) mengatakan wacana adalah satuan bahasa terlengkap yang dinyatakan secara lisan, seperti pidato, ceramah, kotbah, dan dialog atau secara tertulis seperti cerpen, buku, surat yang dilihat dari koheren dan kohesinya. Analisis wacana kritis adalah sebuah upaya pengungkapan suatu pernyataan maksud tersembunyi dari subjek (penulis) yang mengemukakan suatu pernyataan. Analisis wacana kritis juga digunakan untuk mengritik dan mengungkap hubungan antara ilmu pengetahuan dengan kekuasaan (Kridalaksana, 2008:231). Hardiman dalam (Sunarto, 2001:20) menambahkan bahwa konsep kunci untuk memahami teori kritis ini adalah kritik.

Analisis wacana kritis memiliki berbagai macam model, di antaranya Michel Foucault, Roger Fowler, Robert Hodge, Gunther Kress, dan Tony Trew, Sara Mills, Teun A. Van Dijk, Norman Fairclough, dan Theo Van Leeuwen. Setiap model mengkaji analisis wacana kritis secara berbeda. Namun, dibalik perbedaannya tersebut, model-model analisis wacana kritis juga memiliki persamaan yakni semua model menggunakan unit bahasa sebagai alat untuk mendeteksi ideologi teks. (Eriyanto, 2000:343).

Analisis wacana Theo van Leeuwen mendeteksi dan meneliti bagaimana suatu kelompok atau seseorang dimarjinalkan posisinya dalam suatu wacana. Bagaimana suatu kelompok dominan lebih memegang kendali dalam menafsirkan ke dalam suatu peristiwa dan pemaknaannya, sementara kelompok lain yang posisinya rendah cenderung untuk terus-menerus sebagai objek pemaknaan, dan digambarkan secara buruk. Dalam hal ini terdapat kaitan antara wacana dan kekuasaan. Kekuasaan bukan hanya beroperasi lewat jalur-jalur formal, hukum dan institusi negara dengan kekuasannya untuk melarang dan menghukum, tetapi juga beroperasi lewat serangkaian wacana untuk mendefinisikan sesuatu atau suatu kelompok sebagai tidak benar atau buruk. Dan sering kali tindakan kekuasaan itu datang setelah suatu kelompok digambarkan secara buruk (Eriyanto, 2000:171).

Salah satu agen terpenting dalam mendefinisikan suatu kelompok adalah media. Lewat pemberitaan yang terus menerus disebarkan, media secara langsung membentuk pemahaman dan kekuasaan di kepala khalayak mengenai sesuatu. Wacana yang dibuat oleh media itu bisa jadi melegitimasi suatu hal atau kelompok dan medelegitimasikan dan memarjinalkan kelompok lain (Eriyanto, 2000:172).

Model analisis Theo van Leeuwen dapat digunakan untuk melihat bagaimana peristiwa dan aktor-aktor sosial tersebut ditampilkan dalam media, dan bagaimana suatu kelompok yang tidak punya akses menjadi pihak yang secara terus menerus dimarjinalkan. Analisis model Theo van Leeuwen secara umum menampilkan bagaimana pihak-pihak dan pelaku (bisa seseorang atau kelompok) ditampilkan di dalam pemberitaan. Hal itu dilakukan dengan dua pusat perhatian (Eriyanto, 2000:172-173). Pertama, proses pengeluaran, eksklusi (exclusion), yakni apakah di 
dalam satu teks berita ada kelompok atau pelaku yang tidak disebutkan dalam pemberitaan, dan strategi wacana apa yang dipakai di dalam proses exclusion atau eksklusi tersebut. Proses ini secara tidak langsung dapat mengubah pemahaman khalayak akan suatu isu dan melegetimasi posisi pemahaman tertentu. Kedua, proses pemasukan, inkusi (inclusion), yakni suatu proses yang berhubungan dengan pertanyaan bagaimana masing-masing pihak suatu kelompok itu ditampilkan atau disebutkan melalui pemberitaan. Baik proses eksklusi maupun inklusi tersebut menggunakan apa yang disebut dengan strategi wacana. Dengan menggunakan kata, kalimat, informasi, atau susunan bentuk kalimat tertentu, masing-maisng kelompok direpresentaiskan dalam teks.

a. Eksklusi

Ada beberapa strategi bagaimana suatu aktor (seseorang atau kelompok) dikeluarkan dalam pembicaraan. Eksklusi adalah suatu isu yang sentral dalam analisis wacana. Pada dasrnya bagaimana satu kelompok atau aktor tertentu atau tidak dilibatkan dalam suatu pembicaraan atau wacana (Eriyanto, 2000:173).

\section{1) Pasivasi}

Pasivasi adalah satu di antara strategi wacana tentang bagaimana seorang pelaku atau kelompok tertentu atau dikeluarkan atau tidak disebutkan dari pembicaraan di dalam suatu wacana dengan tujuan untuk melindungi pelaku atau kelompok tersebut melalui kalimat dalam bentuk pasif. Melalui pemakaian kalimat pasif, pelaku atau kelompok dapat dihilangkan dalam suatu teks wacana (Eriyanto, 2000:174). Hal ini dapat dilihat pada kalimat dalam tabel berikut ini.

Tabel 1: Contoh Pasivasi

\begin{tabular}{|l|l|}
\hline Aktif & Polisi menembak seorang mahasiswa yang demonstrasi hingga tewas \\
\hline Pasif & Seorang mahasiswa tewas tertembak saat demonstrasi \\
\hline
\end{tabular}

Pada kalimat pertama, berita disajikan dalam bentuk kalimat aktif. Pelaku yakni polisi ditampilkan di dalam teks tersebut. Sebaliknya, pada kalimat kedua, polisi adalah aktor yang dihilangkan di dalam pemberitaan, sebab yang diutamakan di dalam pemberitaan adalah objek, korban penembakan. Dampak tidak baik dari kalimat tersebut ada dua. Pertama, pelaku hilang dari pemberitaan. Wartawan dan khalayak pembaca lebih memperhatikan dan tertarik untuk melihat korban daripada pelaku. Padahal, seperti dalam pemberitaan penembakan tersebut, pelaku penembakan adalah hal yang sangat penting yang sebetulnya layak untuk diketahui oleh pembaca. Kedua, bentuk kalimat pasif yang menghilangkan pelaku dalam kalimat membuat pembaca tidak kritis. Orang hanya akan terfokus pada korban saja daripada pelaku sehingga pelaku dapat bersembunyi karena tidak mendapat perhatian secara kritis dari khalayak pembaca.

\section{2) Nominalisasi}

Nominalisasi adalah strategi wacana yang berhubungan dengan mengubah kata kerja (verba) menjadi kata benda (nomina). Umumnya dilakukan dengan memberi imbuhan pe- dan -an. Nominalisasi dapat menghilangkan pelaku yang seharusnya ada di dalam pemberitaan, hal ini berhubungan dengan transformasi dari bentuk kalimat aktif (Eriyanto, 2000: 176).

Dalam struktur kalimat yang berbentuk aktif, selalu membutuhkan subjek. Kalimat aktif juga selalu berbentuk kata kerja, yang menunjuk pada apa yang dilakukan (proses) oleh subjek. Apabila kita menggunakan kata menembak selalu membutuhkan dua pelaku, yaitu siapa yang menembak dan siapa yang tertembak. Kedua hal tersebut harus ada di dalam kalimat agar kalimat tersebut memilki makna. Sebaliknya, kata benda yang tidak membutuhkan subjek, karena kata benda tersebut bisa berdiri sendiri di dalam kalimat. Misalnya, kata penembakan tidak membutuhkan kehadiran subejk, kata teresbut bisa berdiri sendiri untuk menjelaskan mahasiswa yang meninggal. Hal ini dapat dilihat pada kalimat dalam tabel berikut ini. 
Tabel 2: Contoh Nominalisasi

\begin{tabular}{|l|l|}
\hline Verba & $\begin{array}{l}\text { Polisi menembak seorang mahasiswa yang demonstrasi hingga } \\
\text { tewas. }\end{array}$ \\
\hline Nominalisasi & Seorang mahasiswa tewas akibat penembakan saat demonstrasi. \\
\hline
\end{tabular}

Pada kalimat kedua, pelaku yang menembak (polisi) bisa dihilangkan dalam struktur kalimat ketika kata kerja diubah ke dalam bentuk kata benda. Nominalisasi bukan hanya menghilangkan posisi subjek yang melakukan penembakan, bahkan nominalisasi dapat mengubah makna kalimat ketika diterima oleh khalayak. Nominalisasi tidak membutuhkan subjek, karena nominalisasi pada dasarnya adalah proses mengubah kata kerja yang bermakna tindakan atau kegiatan menjadi kata benda yang bermakna peristiwa.

\section{3) Penggantian Anak Kalimat}

Penggantian subjek juga dapat dilakukan dengan memakai anak kalimat yang sekaligus berfungsi sebagai pelaku. Dalam pemberitaan mengenai demonstrasi mahasiswa, dengan memakai anak kalimat "untuk mengendalikan demonstrasi mahasiswa", maka pelaku (polisi) bisa disembunyikan atau dihilangkan dalam teks (Eriyanto, 2000:178). Perhatikan kalimat dalam tabel berikut ini.

Tabel 3: Contoh Penggantian Anak Kalimat

\begin{tabular}{|l|l|}
\hline $\begin{array}{l}\text { Tanpa anak } \\
\text { kalimat }\end{array}$ & $\begin{array}{l}\text { Polisi menembak seorang mahasiswa yang demonstrasi hingga } \\
\text { tewas. }\end{array}$ \\
\hline Anak kalimat & $\begin{array}{l}\text { Untuk mengendalikan demonstrasi mahasiswa, tembakan terpaksa } \\
\text { dilepaskan }\end{array}$ \\
\hline
\end{tabular}

Pada kalimat pertama, peristiwa penembakan itu ditampilkan tanpa anak kaimat, sedangkan pada kalimat kedua, ditambahkan anak kalimat terutama untuk menjawab pertanyaan mengapa polisi menembak mahasiswa? Jawaban pertanyaan teresbut adalah polisi melakukan penembakan tersebut untuk menghalau dan mengendalikan mahasiswa dan argumentasi ini disajikan di dalam kalimat dengan menempatkannya sebagai anak kalimat.

Pada kalimat kedua, penambahan anak kalimat tersebut bisa menghilangkan keberadan subjek atau pelaku penembakan. Mengapa demikian? Penulis atau wartawan umumnya percaya dan menganggap bahwa khalayak pembaca tahu siapa yang melepaskan tembakan. Oleh karena dianggap tahu dan untuk keefisien kata, polisi sebagai pelaku dihilangkan. Perubahan pada kalimat tersebut tidak mengubah maksud tersembunyi yang ingin disampaikan oleh wartawan. Ada atau tidak adanya anak kalimat di dalam suatu pemberitaan tidak mempengaruhi atau mengubah maksud tersembunyi yang ingin disampaikan oleh wartawan.

\section{b. Inklusi}

Ada beberapa macam strategi wacana yang dilakukan ketika sesuatu, seseorang, atau sekelompok ditampilkan dalam teks. Van Leeuwen (dalam Eriyanto, 2000:179).

\section{1) Diferensiasi-Indiferensiasi}

Suatu peristiwa atau seorang pelaku bisa ditampilkan dalam teks secara mandiri, sebagai suatu peristiwa yang unik atau khas, tetapi juga bisa dibuat kontras dengan menampilkan peristiwa atau pelaku lain di dalam teks. Hadirnya (inklusi) peristiwa atau kelompok lain selain yang diberitakan tersebut menurut van Leeuwen, bisa menjadi penanda yang baik, bagaimana suatu kelompok atau peristiwa direpresentasikan di dalam teks. Penghadiran kelompok atau peistiwa lain, secara tidak langsung ingin menunjukkan bahwa kelompok tersebut tidak baik dibandingkan dengan kelompok lain. Ini merupakan strategi wacana, bagaimana suatu kelompok disudutkan 
dengan menghadirkan kelompok atau wacana lain yang dipandang lebih dominan atau lebih baik (Eriyanto, 2000:180). Misalnya, di dalam pemberitaan mengenai demonstrasi buruh di dalam kalimat pada tabel berikut ini.

Tabel 4: Contoh Diferensiasi-Indiferensiasi

\begin{tabular}{|l|l|}
\hline Indiferensiasi & Buruh pabrik Maspion sampai kemarin masih melanjutkan mogok. \\
\hline Diferensiasi & $\begin{array}{l}\text { Buruh pabrik Maspion sampai kemarin masih melanjutkan mogok, } \\
\text { sementara tawaran direksi yang menawarkan perundingan tidak } \\
\text { ditanggapi oleh buruh. }\end{array}$ \\
\hline
\end{tabular}

Pada kalimat pertama jelas dikatakan, para buruh mogok, sementara pada kalimat kedua ditampilkan fakta mengenai direksi yang menawarkan jalan damai kepada para buruh. Kalimat kedua tersebut secara tidak langsung membedakan antara sikap para pekerja dengan sikap para direksi. Teks tersebut memarjinalkan poisisi buruh dengan menampilkan seakan para buruhlah yang bersikeras untuk melakukan mogok kerja, di lain pihak para direksi ditampilkan sebagai perusahaan yang lebih manusiawi dengan menawarkan perundingan.

Dikatakan memarjinalkan, karena teks tersebut memisahkan sedemikian rupa, proposisi pertama, (buruh yang masih mogok) tidak dianggap sebagai akibat dari proposisi kedua (direksi yang meminta perundingan). Fakta seperti mengapa mereka mogok atau apa yang diinginkan oleh direksi tidak ditampilkan, akibatnya yang tergambar di dalam teks melalui perbedaan pandangan antara cara yang dianggap bagus dengan cara yang tidak dipandang tidak bagus. Diferensiasi sering menimbulkan prasangka tertentu, terutama dengan membuat garis batas antara pihak kita dengan pihak mereka, memarjinalkan pihak mereka dan menguntungkan pihak kita.

\section{2) Objektivasi-Abstraksi}

Strategi wacana ini berhubungan dengan pertanyaan apakah informasi mengenai suatu peristwa atau pelaku sosial ditampilkan dengan diberi petunjuk yang konkret ataukah sebaliknya ditampilkan secara abstraksi.Bandingkan, antara kalimat dengan objektivasi dengan abstraksi berikut (Eriyanto, 2000:181). Berikut contoh kalimat yang membedakan antara objektivasi dengan abstraksi pada tabel berikut ini.

Tabel 5: Contoh Objektivasi-Abstraksi

\begin{tabular}{|l|l|}
\hline Objektivasi & PKI telah 2 kali melakukan pemberontakan \\
\hline Abstraksi & PKI telah berulang kali melakukan pemberontakan \\
\hline
\end{tabular}

Pada kalimat pertama, ditampilkan secara jelas berapa kali PKI melakukan pemberontakan, sementara pada kalimat kedua dengan membuat sesuatu yang abstrak seperti kata "berulangulang". Khalayak akan mempersepsikan secara berbeda antara yang disebut secara jelas dengan yang dibuat dengan bentuk abstraksi. Penyebutan dengan abstraksi, menurut van Leeuwen bukan disebabkan oleh ketidaktahuan wartawan mengenai informasi yang pasti, tetapi lebih dianggap sebagai strategi wacana wartawan untuk menampilkan sesuatu.

\section{3) Nominasi-Kategorisasi}

Dalam suatu pemberitaan mengenai pelaku sosial (seseorang atau kelompok) atau mengenai suatu permasalahan, sering terjadi pilihan apakah pelaku tersebut ditampilkan apa adanya ataukah disebut secara keseluruhan mengenai hal-hal yang berkaitan dengan pelaku sosial tersebut. Kategorisasi ini bisa bermacam-macam, satu diantaranya yang menunjukkan ciri penting dari seseorang, bisa berupa agama, status, bentuk fisik, dan sebagainya.Kategorisasi tersebut sebetulnya tidak penting, karena umumnya tidak mempengaruhi arti yang ingin disampaikan kepada khalayak (Eriyanto, 2000:182). Perhatikan dua kalimat berikut pada tabel di bawah ini. 
Tabel 6: Contoh Nominasi-Kategorisasi

\begin{tabular}{|l|l|}
\hline Nominasi & $\begin{array}{l}\text { Seorang laki-laki ditangkap oleh polisi karena kedapatan membawa } \\
\text { obat-obatan terlarang }\end{array}$ \\
\hline Kategorisasi & $\begin{array}{l}\text { Seorang laki-laki kulit hitam ditangkap oleh polisi karena } \\
\text { kedapatan membawa obat-obatan terlarang }\end{array}$ \\
\hline
\end{tabular}

Kedua kalimat di atas memiliki maksud atau arti yang sama, yakni ada seorang laki-laki yang membawa obat-obataan terlarang dan ditangkap oleh polisi. Pemberian kategori berkulit hitam sama seklai tidak merupakantambahan informasi yang penting siapa sebetulnya laki-laki itu. Mengapa kategori berupa kulit yang ditonjolkan di dalam kalimat itu? Mengapa bukan warga negara dan yang lainnya? Barangkali wartawan tidak secara sengaja menampilkan kategori berupa warna kulit, tetapi secara tidak langsung berita tersebut mengasosiasikan ke dalam pikiran khalayak bahwa warga yang berkulit hitam memang idenetik dengan kekerasan dan obat-obatan.

Menurut van Leeuwen, kategori yang ingin ditonjolkan di dalam pemberitaan bertujuan memberikan inforamsi yang berharga untuk mengetahui lebih dalam mengenai ideologi dari media bersangkutan. Kategori tersebut menunjukkan reperesentasi bahwa suatu tindakan tertentu atau kegiatan tertentu menjadi ciri khas tau atribut yang selalu hadir sesuai dengan kategori yang bersangkutan. Misalnya, di Barat di dalam pemberitaan mengenai terorisme, kategori yang dipakai adalah Islam. Pelaku terorisme selalu diimbuhi dengan kata seperti beragama Islam atau muslimin atau mujahidin.Secara tidak langsung, seakan mengasosiasikan bahwa teorirsme identik dengan warga Islam sehingga tidak ada yang aneh.

\section{4) Nominasi-Identifikasi}

Strategi identifikasi hampir sama dengan kategorisasi di dalam penerapannya, tetapi yang membedakan keduanya adalah di dalam pendefinisian tersebut dilakukan dengan memberi anak kalimat sebagai penjelas. Di sini ada dua proposisi, di mana pada proposisi kedua adalah penjelas atau keterangan dari proposisi pertama.Kalimat yang menggunakan strategi identifikasi, umumnya dihubungkan dengan kata hubung seperti yang dan di mana.Proposisi ke dua tersebut di dalam kalimat, posisinya murni sebagai penjelas atau identifikasi atas sesuatu.

Wartawan barangkali ingin memberikan penjelasan siapa seseorang itu atau apa tindakan atau peristiwa itu. Pemberian penjelasan tersebut mensugestikan makna tertentu, karena umumnya berupa penilaian atas seseorang, kelompok atau tindakan tertentu. Ini merupakan suatu strategi wacana di mana satu orang, kelompok, atau tindakan, diberikan penjelasan yang buruk sehingga diterima oleh khalayak akan buruk pula (Eriyanto, 2000:183). Bandingkan dua kalimat berikut pada tabel di bawah ini.

Tabel 7: Contoh Nominasi-Identifikasi

\begin{tabular}{|l|l|}
\hline Nominasi & Seorang wanita ditemukan tewas, diduga sebelumnya diperkosa \\
\hline Identifikasi & $\begin{array}{l}\text { Seorang wanita, yang keluar malam ditemukan tewas. Diduga } \\
\text { sebelumnya diperkosa. }\end{array}$ \\
\hline
\end{tabular}

Anak kalimat yang sering keluar malam adalah identifikasi yang diberikan oleh wartawan.Identifikasi tersebut bisa menjadi penilaian ke arah mana persitiwa tersebut harus dijelaskan.Dengan memberi anak kalimat yang sering ke luar malam, secara tidak langsung wanita tersebut digambarkan secara buruk, tidak memiliki nlai moral dan etika yang baik, karena seharusnya wanita tidak baik ke luar malam sehingga tidak heran jika mengundang hasrat laki-laki untuk memperkosanya.

Padahal, wanita tersebut keluar malam atau tidak bukan menjadi satu-satunya alasan mengapa dia diperkosa. Sebagai kalimat penjelas, ada atau tidak adanya anak kalimat tersebut 
sama seklai tidak mempengaruhi arti kalimat yang memberitahukan ada wanita yang ditemukan tewas setelah sebelumnya diperkosa.

\section{5) Determinasi- Indeterminasi}

Di dalam pemberitaan, pelaku atau peristiwa disebutkan secara jelas, tetapi sering juga tidak jelas (anonim).Anonimitas ini terjadi karena wartawan belum mendapatkan bukti yang cukup untuk menulis, sehingga lebih aman untuk menulis anonim.Bisa juga karena ada ketakutan struktural jika kategori yang jelas dari seorang pelaku sosial tersebut disebut di dalam teks.Alasannya, dengan membentuk anonimitas tersebut, ada kesan yang berbeda ketika diterima oleh khalayak pembaca. Hal ini dikarenakan anonimitas menurut van Leeuwen justru membuat suatu generalisasi, tidak spesifik (Eriyanto, 2000:185). Berikut contoh kalimat yang membedakan antara determiniasi dengan indeterminasi pada tabel di bawah ini.

Tabel 8: Contoh Determinasi-Indeterminasi

\begin{tabular}{|l|l|}
\hline Determinasi & Menlu Alwi Shihab disebut-sebut terlibat skandal Bulog \\
\hline Indeterminasi & Orang dekat Gus Dur disebut-sebut terlibat dalam skandal Bulog. \\
\hline
\end{tabular}

Pada contoh kalimat di atas, kalimat pertama, nama pelaku sosial disebutkan secara jelas dan spesifik (Alwi Shihab). Pada kalimat kedua, pelaku sosial tidak disebutkan secara jelas dan spesifik sehingga tidak lagi bermakna tunggal melainkan bermakna jamak.Menegaskan bahwa ada beberapa orang memiliki hubungan dekat dengan Gus Dur yang terlibat kasus Bulog.Melalui indeterminasi, maksud yang ingin disampaikan oleh wartawan kepada khalayak dapat diterima secara jelas, karena peristiwa yang ditampilkan dijelaskan secara spesifik. Berbeda dengan indeterminasi, determinasi justru memberikan gambaran yang samar atau tidak jelas di dalam suatu pemberiaan sehingga khalayak menemui kesulitan untuk menangkap maksud yang tersembunyi di dalamnya.

\section{6) Asimilasi-Individualisasi}

Strategi ini berhubunagn dengan pertanyaan, apakah pelaku sosial yang diberitakan ditunjukkan dengan jelas kategorinya atau tidak.Asimilasi terjadi ketika di dalam pemberitaan bukan kategori pelaku sosial yang spesifik yang disebut di dalam berita, melainkan komunitas atau kelompok sosial di mana seseorang tersebut berada (Eriyanto, 2000:187). Perhatikan kalimat dalam tabel berikut ini.

Tabel 9: Contoh Asimilasi-Individualisasi

\begin{tabular}{|l|l|}
\hline $\begin{array}{l}\text { Individualisa } \\
\text { si }\end{array}$ & $\begin{array}{l}\text { Adi, mahasiswa Tri Sakti tewas ditembak Parman, seorang polisi, } \\
\text { dalam demonstrasi di Cendana kemarin. }\end{array}$ \\
\hline Asimilasi & $\begin{array}{l}\text { Mahasiswa tewas ditembak polisi, dalam demonstrasi di Cendana } \\
\text { kemarin. }\end{array}$ \\
\hline
\end{tabular}

Kalimat pertama adalah bentuk individualisasi, karena di sana kategori mahasiswa disebut secara jelas. Jika tidak disebutkan di dalam teks, berita tersebut tetap menegaskan bahwa yang meninggal dalam demonstrasi tersebut adalah satu orang mahasiswa.Hal ini berbeda bila dibandingkan pada kalimat kedua dalam bentuk asimilasi.Dalam kalimat tersebut, tidak disebut Adi (mahasiswa yang meninggal), tetapi yang diacu adalah komunitas yang bernama mahasiswa.Demikian juga dengan Parman yang disebut sebagai polisi. Bentuk kalimat kedua dengan menggunakan strategi wacana asimilasi, makna atau kesan yang diterima oleh khalayak akan berbeda dengan kalimat pertama. Melalui strategi wacana ini, digambarkan begitu banyak mahasiswa yang tertembak, mengesankan semua mahasiswa menjadi korban.Demikian hanya dengan polisi yang dikesankan semua polisi melakukan penembakan.

\section{7) Asosiasi-Disosiasi}


Strategi wacana ini berhubungan dengan pertanyaan, apakah pelaku atau suatu pihak ditampilkan sendiri atau dihubungkan dengan kelompok lain yang lebih besar. Elemen asosiasi ingin melihat apakah suatu peristiwa atau pelaku sosial dihubungkan dengan peristiwa lain atau kelompok lain yang lebih luas. Ini adalah proses yang sering terjadi tanpa kita sadari (Eriyanto, 2000:189).

Jika ada tentara menembak mahasiswa, khalayak pembaca bukan hanya menilai secara khusus kasus tersebut, tetapi juga menghubungkan dengan perilaku militer yang memang sering melakukan penembakan dan berjiwa militer.J ika ada pejabat yang bersangkutan terlibat dalam kasus Bulog, tetapi tidak diiperiksa, khalayak pembaca sering juga menghubungkan dengan peristiwa yang lain seperti Bank Bali. Tentu saja tidak ada hubungan antara kasus Bulog dengan kasus Bank Bali, namun secara imajinatif dapat dihubungkan secara literer bahwa ini menunjukkan watak atau pola pemerintah Indonesia yang tidak tegas pada para koruptor. Perhatikan contoh kalimat pada tabel di bawah ini.

Tabel 10: Contoh Asosiasi-Disosiasi

\begin{tabular}{|l|l|}
\hline Disosiasi & $\begin{array}{l}\text { Sebanyak 40 orang muslim meninggal dalam kasus Tobelo, } \\
\text { Galela, dan Jailolo. }\end{array}$ \\
\hline Asosiasi & $\begin{array}{l}\text { Umat islam di mana-mana selalu menjadi sasaran pemberitaan. } \\
\text { Setelah di Bosnia, sekarang di Ambon. Sebanyak 40 orang muslim } \\
\text { meninggal dalam kasus Tobelo, Galela, dan Jailolo. }\end{array}$ \\
\hline
\end{tabular}

Pada kalimat pertama, umat Islam yang meninggal dalam kasus Tobelo, Galela, dan Jailolo tidak dihubungkan dengan kelompok yang lebih luas. Sementara pada kalimat yang kedua, umat Islam yang meninggal diasosiasikan dan dihubungkan dengan umat Islam di negara-negara lain. Dengan memberikan asosiasi seperti itu, represenatsi mereka yang meninggal menjadi berbeda.Pada kalimat pertama, kasus Ambon tersebut dipandang sebagai kasus spesifik, lokal, dan berlaku hanya untuk wilayah Ambon. Sementara kalimat yang kedua justru sebaliknya, mereka yang meninggal dihubungkan atau diasosiasikan dengan mereka yang mrninggal di Bosnia. Oleh karena itu, kasus Tobelo, Galela, dan Jailolo tidak dianggap sebagai kasus lokal Ambon, tetapi juga kasus umat islam secara keseluruhan.

Apa yang terjadi di Ambon secara tidak langsung diasosiasikan menggambarkan apa yang terjadi di dunia Islam secara keseluruhan. Umat Islam dipandang menjadi korban pembantaian, dengan demikian, strategi asosiasi membuat khalayak membayangkan dan menghubungkan secara imajiner dengan komunitas yang lebih luas. Kasus Ambon dan Bosnia adalah dua peristiwa yang terpisah, tetapi dengan asosiasi dapat dibuat hubungan imajiner di antara kedua peristiwa tersebut sehingga berhubungan. 


\section{METODOLOGI}

Jenis penelitian ini adalah penelitian kualitatif dengan menggunakan metode deskriptif. Moleong (2007: 7) menyatakan bahwa penelitian kualitatif adalah penelitian yang lebih banyak mementingkan proses daripada hasil. Data penelitian ini adalah teks berita dengan permasalahan kriminal pada surat kabar Posmetro Padang. Sumber data penelitian ini adalah berita harian Posmetro Padang. Media cetak yang dipilih adalah Posmetro Padang pada tema kriminal karena media cetak ini lebih memfokuskan beritanya pada permasalahan kriminal. Berita kriminal yang ditampilkan hampir setiap hari dan masalah kriminal selalu menjadi sorotan masyarakat.

Teknik pengumpulan data dalam penelitian ini terdiri atas tahapan-tahapan sebagai berikut: (1) membaca dan memahami teks berita Posmetro Padang, (2) melakukan pencatatan data. Pencatatan dilakukan dengan menggunakan lembar pencatatan yang dibuat untuk keperluan mengumpulkan data. Selanjutnya, menandai dan mencatat data-data berupa strategi ekslusi dan inklusi.

Berdasarkan teknik analisis data kualitatif, dapat disusun langkah-langkah penganalisisan dan penelitian ini sebagai berikut. Pertama, membaca dan memahami sumber data yang telah terkumpul secara keseluruhan. Kedua, mencatat sesuai topik yang dibahas berdasarkan lembaran pencatatan. Ketiga, mengelompokkan kalimat-kalimat berdasarkan strategi ekslusi dan inklusi dalam berita kriminal surat kabar harian Posmetro Padang. Keempat, strategi ekslusi dan inklusi tersebut dianalisis berdasarkan ideologi yang diperjuangkan dan dimarjinalkan yang mengindikasi penyalahgunaan kekuasaan. Kelima, melakukan pembahasan dari temuan dan dikaitkan dengan teori mengenai strategi eksklusi dan inklusi berdasarkan analisis ideologi yang diperjuangkan dan dimarjinalkan yang mengidentifikasikan penyalahgunaan kekuasaan.

\section{HASIL DAN PEMBAHASAN}

Analisis wacana kritis ini menggunakan model analisis Theo van Leeuwen pada salah satu teks berita Posmetro Padang, 19 Mei 2014 yang berjudul Sopir Truk Semen Ditangkap Edarkan Ganja. Analisis wacana kritis berita tersebut didasarkan pada dua bagian, yaitu ekslusi dan inklusi. a. Eksklusi

Strategi wacana eksklusi ditandai dengan penggunaan kalimat pasif (pasivasi), mengubah kata kerja (verba) menjadi kata benda (nominal) dengan memberikan imbuhan"pe-an" at atau "kean" (nominalisasi), dan menggunakan anak kalimat pengganti subjek (penggantian anak kalimat). Pertama, penggantian kalimat pasif (pasivasi). Penggunaan kategori ini dalam sebuah pemberitaan pada dasarnya bertujuan untuk tidak melibatkan atau sengaja menghilangkan pelaku atau kelompok sosial tertentu dalam suatu pembicaraan atau wacana (Eriyanto, 2006:173). Penghilangan tersebut dilakukan untuk melindungi pelaku yang seharusnya dilibatkan dalam pemberitaan. Berikut ini beberapa kutipan yang mengandung pasivasi yang ditemukan dalam teks tersebut.

Sopir truk pengangkut semen diciduk jajaran Direktorat Reserse Narkoba Polda Sumbar, Senin (19/5) sekitar pukul 12.30 WIB. Pria bertato yang bernama Indra Jaya alias In Tato (29) tersebut ditangkap saat dipancing petugas di rumahnya di kawasan Kampung Pinang, Kecamatan Kuranji. ( Posmetro Padang, 19 Mei 2014)

Penggunaan kategori pasivasi ditandai dengan penggunaan kata diciduk pada teks berita tersebut. Kata diciduk dan ditangkap pada kalimat tersebut menyembunyikan atau tidak melibatkan pelaku atau kelompok sosial dalam pemberitaan. Secara ideologi, ideologi yang diperjuangkan dalam kutipan teks berita tersebut yaitu ideologi dari jajaran Direktorat Reserse 
Narkoba Polda Sumbar. Sementara yang lebih diperjuangkan orang yang akan menyampaikan peristiwa tersebut.

Tidak menunggu lama, pelaku langsung diciduk petugas yang sudah mengintai disekitar lokasi transaksi. Petugas langsung melakukan pengeledahan, dan ditemukan 14 paket narkoba bervariasi mulai dari paket besar, sedang dan kecil di dalam sakunya. Dan setelah diperiksa lagi, petugas kembali menemukan satu paket kecil ganja dari dalam dompet pelaku.(Posmetro Padang, 19 Mei 2014)

Penggunaan kategori pasivasi pada kutipan tersebut ditandai dengan penggunaan kata diciduk pada teks berita tersebut. Kata diciduk pada kalimat tersebut menyembunyikan atau tidak melibatkan pelaku atau kelompok sosial dalam pemberitaan. Salah satu tujuan wartawan yang tidak melibatkan pelaku dalam pemberitaannya adalah agar khalayak pembaca lebih terfokus pada objek pemberitaan yaitu supir truk pengangkut semen yang diceritakan sebagai orang yang bersalah.

Saat ditangkap petugas, pelaku ini sempat berkilah dan bahkan melawan petugas, namun dia tidak berdaya karena barang bukti sudah didapatkan dari dalam dompet dan sakunya. Pelaku pun langsung digelandang ke markas Polda. (Posmetro Padang, 19 Mei 2014)

Dalam kutipan di atas supir truk ditangkap oleh petugas sehingga pembaca akan terfokus bahwa kesalahan terpusat kepada supir truk pengangkut semen. Jadi pihak yang diunggulkan dalam kutipan teks berita tersebut adalah jajaran Direktorat Reserse Narkoba Polda Sumbar dan pihak yang dimarginalkan adalah supir truk pengangkut semen. Supir truk menjadi pihak yang dimarginalkan dalam kutipan teks berita tersebut.

Kedua, strategi wacana eksklusi dilakukan melalui penggunaan kategori nominalisasi yakni suatu proses yang mengubah kata kerja (verba) menjadi kata benda (nomina) dengan memberikan imbuhan "pe-an" atau "ke-an" (Eriyanto, 2006:175). Berikut ini kutipan teks berita yang menggunakan strategi wacana eksklusi dalam kategori nominalisasi.

Informasi yang dihimpun Posmetro Padang (grup JPNN), penangkapan terhadap In Tato yang sudah menjadi DPO ini bermula dari pengintaian yang dilakukan oleh persone opsnal Dir Narkoba Polda Sumbar. Dengan berpura-pura sebagai mahasiswa dan memancing pelaku ini untuk bertransaksi. (Posmetro Padang, 19 Mei 2014)

Penggunaan kategori nominalisasi ditandai dengan penggunaan kata penangkapan dan pengintaian pada teks berita tersebut. Dalam hal ini, penggunaan kata kerja akan membutuhkan pelaku dan objek tetapi kata benda tidak. Misalnya, kata menangkap dan mengintai membutuhkan pelaku yang melaksanakan dan mengumumkan suatu objek. Namun, dalam teks sengaja dibendakan sehingga orang yang bertanggung jawab melaksanakan tersebut dapat disembunyikan. Dalam hal ini jajaran Direktorat Reserse Narkoba Polda Sumbar adalah yang disembunyikan.

Nominalisasi tidak hanya menghilangkan posisi subjek, tetapi juga dapat mengubah makna kalimat ketika diterima oleh khalayak. Nominalisasi tidak membutuhkan subjek, karena nominalisasi pada dasarnya adalah proses mengubah kata kerja yang bermakna tindakan atau kegiatan menjadi kata benda yang bermakna peristiwa.

Ketiga, kategori terakhir dalam strategi wacana eksklusi adalah kategori penggantian anak kalimat. Kategori ini merupakan pengganti pelaku sehingga yang muncul adalah alasan pelaku mengambil suatu tindakan, sementara pelaku sendiri menjadi tidak tampak dalam wacana.

"Untuk mempertanggungjawabkan perbuatannya, pelaku ini terancam pasal 119 ayat 1 UU No 35 tahun 2009 tentang Narkotika dengan ancaman kurungan 20 tahun penjara," tukasnya. (Posmetro Padang, 19 Mei 2014)

Kutipan teks berita tersebut menggunakan strategi wacana eksklusi dalam kategori penggantian anak kalimat. Penggantian subjek juga dapat dilakukan dengan memakai anak kalimat yang sekaligus berfungsi sebagai pelaku. Kalimat tersebut menyatakan alasan mengapa supir truk 
diciduk jajaran Direktorat Reserse Narkoba Polda Sumbar sehingga supri truk memang ternyata benar terbukti bersalah.

Jadi, untuk dapat mengetahui pelaku, pihak, dan kelompok yang disembunyikan oleh media dalam teks berita dapat dilakukan dengan menganalisis ekslusi yang mencakup tiga unsur, yaitu pasivasi, nominalisasi, dan penggantian anak kalimat.

b. Inklusi

Strategi kedua yang digunakan dalam teks berita adalah strategi wacana inklusi. Strategi ini berkaitan dengan bagaimana cara seorang wartawan atau penulis berita menampilkan atau mempresentasikan peristiwa di dalam sebuah pemberitaan dengan tidak melibatkan pelaku atau kelompok sosial tertentu (Eriyanto, 2000:173). Strategi ini meliputi tujuh kategori yakni kategori diferensiasi-indiferensiasi, objektivasi-abstraksi, nominasi-kategorisasi, nominasi-identifikasi, determinasi-indeterminasi, asimilasi-individualisasi, dan asosiasi-disosiasi.

Strategi wacana inklusi berbeda dengan strategi wacana eksklusi. Wartawan atau penulis berita menampilkan secara jelas peristiwa dan melibatkan pelaku atau kelompok sosial yang dimaksudkan dalam teks berita mengenai pengambilan keputusan pemerintah dengan maksud untuk memarjinalkan. Berikut ini kutipan atau penggalan teks berita yang menggunakan strategi wacana inklusi.

Berdasarkan analisis berita yang berjudul Sopir Truk Semen Ditangkap Edarkan Ganja terdapat beberapa penggunaan strategi wacana inklusi yaitu sebagai berikut. Pertama, penggunaan kategori diferensiasi-indiferensiasi. Penggunaan kategori ini oleh wartawan atau penulis berita adalah untuk mempresentasikan perbedaan sikap antara kedua belah pihak yang kontras. Penggunaan kategori deferiensiasi dapat dilihat pada kutipan teks berikut ini.

Saat ditangkap petugas, pelaku ini sempat berkilah dan bahkan melawan petugas, namun dia tidak berdaya karena barang bukti sudah didapatkan dari dalam dompet dan sakunya. Pelaku pun langsung digelandang ke markas Polda. (Posmetro Padang, 19 Mei 2014)

Dari pengakuan pelaku, dia menyebut baru tiga kali berhasil mengedarkan narkoba jenis sabu-sabu ini di kawasan Kuranji. Tapi, polisi tidak percaya begitu saja dengan keterangan pelaku. Barang bukti yang didapat cukup membuktikan kalau pelaku ini adalah seorang bandar. (Posmetro Padang, 19 Mei 2014)

Kutipan teks berita di atas menampilkan secara kontras peristiwa dan pelaku social dalam sebuah teks berita melalui penggunaan dua proposisi. Pada teks berita tersebut, memarjinalkan posisi supir truk.

Kedua, pengunaan kategori objektivasi-abstraksi. Kategori ini berhubungan dengan informasi mengenai suatu peristiwa atau pelaku sosial yang ditampilkan dengan memberi petunjuk yang konkret (objektivasi) atau sebaliknya tidak jelas (abstraksi). Untuk kategori ini tidak terdapat di dalam teks.

Ketiga, pengunaan strategi wacana inklusi dalam kategori nominasi-kategorisasi. Kategori nominasi-kategorisasi merupakan pilihan untuk menampilkan pelaku apa adanya atau justru menampilkannya berdasarkan kategori-kategori berupa ciri penting seperti, agama, status, bentuk fisik dan sebagainya. Perhatikan penggalan teks berita berikut ini.

Sopir truk pengangkut semen diciduk jajaran Direktorat Reserse Narkoba Polda Sumbar, Senin (19/5) sekitar pukul 12.30 WIB. Pria bertato yang bernama Indra Jaya alias In Tato (29) tersebut ditangkap saat dipancing petugas di rumahnya di kawasan Kampung Pinang, Kecamatan Kuranji. (Posmetro Padang, 19 Mei 2014)

"Melihat pelaku ini mengeluarkan barang bukti, kami langsung bergerak mendekat. Saat transaksi itu akan selesai, kami langsung ciduk pelaku ini," papar Direktur Direktorat Reserse Narkoba Polda Sumbar, Kombes Pol Alam Syah M melalui Kasubnit I Opsnal, AKP Efriandi Aziz, kemarin. (Posmetro Padang, 19 Mei 2014) 
Strategi wacana inklusi dalam kategori nominasi-kategorisasi yang terlihat pada penggalan berita tersebut adalah Indra Jaya alias In Tato, Alam Syah $M$ dan AKP Efriandi Aziz sebagai pelaku sosial tidak ditampilkan apa adanya. Dalam hal ini, penulis berita atau wartawan menambahkan kategori pada pelaku sosial. Kategori yang ditambahkan pada Indra Jaya alias In Tato adalah pria bertato. Kategori yang ditambahkan pada Alam Syah $M$ adalah Direktur Direktorat Reserse Narkoba Polda Sumbar dan AKP Efriandi Aziz adalah Kasubnit I Opsnal .

Keempat, penggunaan kategori nominasi-identifikasi. Nominasi-identifikasi merupakan kategori strategi wacana inklusi yang hampir sama dengan kategorisasi, hanya saja dalam identifikasi proses pendefinisian pelaku, kelompok, atau suatu peristiwa dilakukan dengan memberikan anak kalimat sebagai penjelas dan secara umum dihubungkan dengan kata: yang atau di mana.

Sopir truk pengangkut semen diciduk jajaran Direktorat Reserse Narkoba Polda Sumbar, Senin (19/5) sekitar pukul 12.30 WIB. Pria bertato yang bernama Indra Jaya alias In Tato (29) tersebut ditangkap saat dipancing petugas di rumahnya di kawasan Kampung Pinang, Kecamatan Kuranji. (Posmetro Padang, 19 Mei 2014)

Kelima, penggunaan strategi wacana inklusi dalam kategori determinasi-indeterminasi. Determinasi merupakan strategi wacana yang menampilkan peristiwa, pelaku, atau kelompok sosial dengan tidak disebutkan secara tidak jelas (anonim) (Eriyanto, 2006:186). Waratawan atau penulis berita belum mendapatkan bukti yang cukup untuk menulis atau karena ada ketakutan struktural kalau kategori disebutkan secara jelas dari seorang pelaku sosial dalam teks akan menimbulkan masalah bagi wartawan tersebut. Penggunaan yang terlihat dalam teks berita pada umumnya menggunakan indeterminasi.

Sopir truk pengangkut semen diciduk jajaran Direktorat Reserse Narkoba Polda Sumbar, Senin (19/5) sekitar pukul 12.30 WIB. Pria bertato yang bernama Indra Jaya alias In Tato (29) tersebut ditangkap saat dipancing petugas di rumahnya di kawasan Kampung Pinang, Kecamatan Kuranji. (Posmetro Padang, 19 Mei 2014)

Keenam, penggunaan strategi wacana inklusi dalam kategori asimiliasi-individualisasi. Penggunaan kategori tersebut dilakukan dengan cara tidak menampilkan pelaku sosial secara jelas justru komunitas pelaku tersebut berada yang secara spesifik ditampilkan (asimilasi) dan sebaliknya menampilkannya pelaku dan komunitasnya secara jelas dan spesifik (individualisasi) dalam pemberitaan. Dalam teks berita, penggunaan kategori asimilasi dan individualisasi dilihat pada kutipan teks berita di bawah ini.

Sopir truk pengangkut semen diciduk jajaran Direktorat Reserse Narkoba Polda Sumbar, Senin (19/5) sekitar pukul 12.30 WIB. Pria bertato yang bernama Indra Jaya alias In Tato (29) tersebut ditangkap saat dipancing petugas di rumahnya di kawasan Kampung Pinang, Kecamatan Kuranji. (asimilasi) (Posmetro Padang, 19 Mei 2014)

Sopir truk pengangkut semen diciduk jajaran Direktorat Reserse Narkoba Polda Sumbar, Senin (19/5) sekitar pukul 12.30 WIB. Pria bertato yang bernama Indra Jaya alias In Tato (29) tersebut ditangkap saat dipancing petugas di rumahnya di kawasan Kampung Pinang, Kecamatan Kuranji.(individualisasi) (Posmetro Padang, 19 Mei 2014)

"Melihat pelaku ini mengeluarkan barang bukti, kami langsung bergerak mendekat. Saat transaksi itu akan selesai, kami langsung ciduk pelaku ini," papar Direktur Direktorat Reserse Narkoba Polda Sumbar, Kombes Pol Alam Syah M melalui Kasubnit I Opsnal, AKP Efriandi Aziz, kemarin. (individualisasi) (Posmetro Padang, 19 Mei 2014)

Ketujuh, penggunaan strategi wacana inklusi dalam kategori asosiasi-disosiasi. Penggunaan kategori ini dapat dilakukan dengan cara menghubungkan peristiwa, pelaku, atau kelompok sosial yang menjadi pemberitaan dengan asosiasi atau kelompok yang lebih besar di mana pelaku sosial itu berada (asosiasi) atau tidak menghubungkannya sama sekali dengan 
asosiasi atau kelompok yang lebih besar di mana aktor tersebut berada (disosiasi). Penggunaan kategori asosiasi tidak terdapat di dalam teks.

Jadi, dapat diketahui bahwa pihak yang diunggulkan dalam teks berita tersebut adalah jajaran Direktorat Reserse Narkoba Polda Sumbar. Pihak yang diunggulkan tersebut dengan cara ekslusi pada uraian di atas. Pihak yang dimarjinalkan adalah supir truk yang membawa semen, pria bertato yang bernama Indra Jaya alias In Tato (29). Pihak yang dimarjinalkan dalam berita tersebut melalui cara inklusi. Indikasi penyalahgunaan kekuasaan dan pembelokan kebenaran dalam teks berita ini terlihat bahwa dalam teks terkesan lebih mengunggulkan pihak jajaran Direktorat Reserse Narkoba Polda Sumbar, sedangkan pihak yang dimarjinalkan adalah adalah supir truk yang membawa semen, pria bertato yang bernama Indra Jaya alias In Tato (29).

\section{KESIMPULAN}

Berdasarkan analisis yang dilakukan terhadap berita tersebut, dapat disimpulkan bahwa pihak yang diunggulkan dalam beritu tersebut adalah jajaran Direktorat Reserse Narkoba Polda Sumbar sedangkan pihak yang dimarjinalisasikan adalah supir truk yang membawa semen yaitu pria bertato yang bernama Indra Jaya alias In Tato. Hal ini terlihat pada strategi inklusi Direktorat Reserse Narkoba Polda Sumbar menjadi pihak yang sering dimunculkan atau dibicarakan.

Selanjutnya, model analisis wacana kritis Theo van Leeuwen merupakan satu dari enam model analisis wacana kritis yang memungkinkan khalayak pembaca untuk mengetahui bagaimana suatu kelompok atau seseorang dimarjinalkan atau malah diunggulkan posisinya dalam suatu wacana berita. Selain itu, membantu agar pembaca dapat berpikir lebih kritis dalam menganalisis sebuah wacana berita. Tidak hanya membaca akan tetapi memahami dan memaknainya sehingga dapat mengetahui maksud yang tersembunyi dalam teks berita tersebut.

\section{Referensi}

\section{Alfianika, Ninit. 2016. Analisis Wacana Kritis Teori Inclusion Theo Van Leeuwen dalam Berita Kriminal Tema Pencurian Koran Posmetro Padang Edisi Mei 2013. Jurnal Penelitian Bahasa dan Sastra Indonesia V2.i1 (33-43)}

Alwi, Hasan dkk. 2003. Tata Bahasa Baku Bahasa Indonesia (Edisi Ketiga). Jakarta: Balai Pustaka.

Basrowi dan Suwandi. 2008. Memahami Penelitian Kualitatif. Jakarta: PT Asdi Mahasatya.

Darma, Y. A. 2009. Analisis Wacana Kritis. Bandung: Yrama Widya.

Eryanto. 2000. Analisis Wacana:Pengantar Analisis Wacana. Yogyakarta: LkiS.

Moleong, Lexy J. 2007. Metodologi Penelitian Kualitatif. Bandung: Rosdakarya.

Kamus Besar Bahasa Indoensia Online

Kridalaksana, H. 2008. Kamus Linguistik. Edisi Revisi. Jakarta: PT Gramedia Pustaka Utama

Keraf, G. 1999. Diksi dan Gaya Bahasa. Jakarta: Gramedia Pustaka Utama. 
Oktavia, Yunisa dan Frangky Silitonga. Implementasi Analisis Wacana Kritis Perspektif Leeuwen dalam Berita Politik Surat Kabar Padang Ekspres terhadap Pembelajaran Bahasa Berbasis Teks . Halaman 201 - 213 Volume 1, No. 2, September 2016

Posmetro Padang. 2014. “Sopir Truk Semen Ditangkap Edarkan Ganja”. Senin, 19 Mei 2014, 23:05:00.

Setiawan, Yuliyanto Budi Setawan. 2011. Analisis Wacana Kritis Pemberitaan Kekerasan Berbasis Gender di Surat Kabar Harian Suara Merdeka. Jurnal Ilmiah Komunikasi |MAKNA Vol. 2 no. 1, Pebruari 2011

Sunarto, Agus. 2001. Politik Media dan Pertarungan Wacana. Yogyakara: LKIS.

Sumarlan, dkk. 2003. Teori dan Praktik Analisis Wacana. Surakarta: Pustaka Cakra. 